\begin{tabular}{|c|c|}
\hline & \\
\hline Idamoyibo Atinuke Adenike & \\
\hline $\begin{array}{l}\text { Idamoyibo Atinuke Adenike (PhD) is } \\
\text { Senior Lecturer at Delta State Uni- } \\
\text { versity, Nigeria, where she teaches }\end{array}$ & $\begin{array}{l}\text { drumming, and the tradition of the } \\
\text { dùndún and the bàtá ensemble of }\end{array}$ \\
\hline $\begin{array}{l}\text { African Music. She specializes in oral } \\
\text { genres and has published widely. }\end{array}$ & South Western Nigeri \\
\hline
\end{tabular}

\title{
The media, the reconstruction of drumming, and the tradition of the dùndún and the bàtá ensemble of the Yorùbá in South Western Nigeria
}

This paper examines the impact of the technical media in the reconstruction of Yorùbá traditional drum music, for example given by the unification of two important ensemble instruments in Yorùbá society. It also calls to 'revive' the indigenous system of drumming beyond its traditional setting, making it an issue of global consumption. The preservation of the instrumental heritage of the Yorùbá people of South Western Nigeria needs to be discussed in its association with technical media. The Prodigal Ones by Mount Zion Films Production (and other drum music performance in films) shows the media enhancement of the performance of the ensemble serving as accompaniment during a traditional festival. The short scene allocated to a traditional festival reveals the significance of drumming and the input of the drum makers, who are generally not educated but are rich in ideas, knowledge and skills. Interviews show that the dùndún and bàtá ensemble today showcase a new image that is colourful. The wood for drum's construction is now lighter than for the older ones. Keywords: diffusion, dùndún and bàtá ensemble, media documentation, traditional drumming, Yorùbá traditional music.

\section{Introduction}

The field of traditional music in Africa has been widened and the scope of communication promoted through media devices. For example, independent forms of solo or duet performances are accommodated in the body of core traditional drumming role. Moreover, the technical media have affected the creation and communication of drum music positively: the amplification of festival drum music through the radio and other broadcasting devices has up-graded the quality of drum music production. Finally, the rigidity of traditional boundary that restricts drum music to festivals has been broken by the new technology. The $21^{\text {st }}$ century drum music showcases heightened performances that were born out of the yearly festival recordings and the drummers' close links with the Nigeria Television Authority in Yorùbá land. This plays a significant role in connecting human and material objects in a chain of music broadcasting. After a short presentation of traditional drumming ensembles and methods of drum construction, this article discusses some elements of the social evolution and the 'reinvention' of Yorùbá drumming art. 
The technical media and its impact in the preservation of the drumming heritage The significance of the media in the preservation of indigenous knowledge in $21^{\text {st }}$ century musical practice cannot be overestimated. The performance of ensemble music has found a new avenue of expression beyond the ancient limited setting that kept 'chief' drummers and all their activities bound to the palaces of kings in Yorùbá land. There are two categories of drummers in the traditional Yorùbá culture, the Ijoye Onilu (court musicians) and the minority drummers. The latter are not as organized and accorded much respect as the former. In fact they are regularly addressed as beggars. They also do not have links with the media probably because of their poor general outlook and their roaming disposition. The former, however, perform through films and documentaries because of their significant positions as court musicians. The dùndún/bàtá ensembles now form an alliance with the media that re-direct or shape its involvement in performances. New media contribute to preserve the drumming genre by fixing it permanently in a reproducible and tangible form thanks to CDs and DVDs, which transforms its original local setting into an unlimited one. This development has furthermore created a new space of interaction between Yorùbá youth and the drumming art.

Moreover, the intervention of the media has broken the jinx that once, for reasons related to the sphere of the sacred, restricted the merging of ensemble genres. Originally, the merging of ensembles was forbidden in Yorùbá land but as the worship of deities to whom the drums were dedicated depreciates the restrictions fizzles out. The consciousness of the output of the new drumming sound production encourages the integration of the kúdi (three sets of drums tied together firmly by leather traps, made to produce three distinct tones, low middle and high) that now adds its vigorous and sonorous tones to the existing pleasant qualities of the dùndún. This inclusion has broadened the harmonic impact of the sounds emerging from the combination of drums.

Another change brought about by the new technology has taken drum music to a higher and more organised level by extending its performance beyond the venue where music is performed. The 'invisible' public of radio and television now rightfully assess and rate the performances and the artistes. The transmission of drum music on television has added both positive and negative new dimensions to its communication. The positive aspect is that the beauty of skilful drum performances are retained and preserved, but the negative aspect is that faults, sometimes very glaring faults, in live performance recordings are also retained, which is sufficient enough to discourage a young drumming group. However, performance errors are also useful for selfassessment and future modification.

The traditional performance of a local genre in a film entitled the Prodigal Ones (by Mount Zion Film Production in Nigeria) shows a number of relevant interactions between drumming performance and television coverage. The order of superiority 
and historical significance of the drummers is grasped from the İgbàlè, the traditional dressing space of the masquerade spirit in Yorùbá land. The chief master drummers lead the procession of the masquerade spirit; this shows the ranking of the spirit manifested in human form. The leader of the drummers appears to be conscious of the camera coverage; he was perhaps aware that the recording would enhance the popularity that could be gained from the media coverage of the festival, which could also mean the promotion of his skill and versatility. However, his performance on the drum does not reflect a nervous state. All the drummers are elderly prolific master artistes; their versatility is enhanced by the close-ups of the performance that reveal the energy that they exerted in the manipulation of the membrane of the talking drums.

The performance on CDs presents a very colourful event. This may be attributed to the electric light used to aid the recording of the film. Another noticeable observation is that the recording makes possible to adjust the volume, while the live performance of the genre is without the use of amplification devices and cannot be regulated. The best one could do is to cope with the loud volume of the performance.

As indicated above, accurate preservation of the genre is another important significance of the media interaction with the drumming ensembles. The recording presents all angles of the performance and gives the viewers the opportunity to review it as many times as possible, ensuring thus a firm assimilation and memorization. Recordings of drumming are, under this aspect, a prolongation of its dynamic existence, which makes the media a valid form of artistic preservation. The permanent availability of the drumming performances on $\mathrm{CD}$ and DVD is gradually promoting sales, even when there is no immediate need for the purchase. The buyer satisfies his/ her desire to listen to and to watch the drumming ensembles rather than a practical reason, such as the need of such music for a ritual. The purchase, in one way or the order, contributes to the promotion of the festival. The short scene of the festival in the film ends with a grandiose style when the drummers present the conclusive moment of the performance by punctuating their drums and ending at the same time.

It is useful, at this point, to introduce the traditional drumming ensembles (methods of drum construction, playing technique, and apprenticeship are included in the appendix).

\section{The representation of the dùndún and the bàtá ensemble as an aspect of indigenous knowledge}

The drumming ensemble is an oral genre that is peculiar to the identity of the musical culture of the Yorùbá. The most popular of all ensembles in the land is the dùndún and bàtá. This is in agreement with Oláníyan ("Musical Practice" 46) who notes that "out of many traditional instrumental ensembles of the Yorùbá in Nigeria, dùndún stands 
out as the most popular." The dùndún is an all drum ensemble that comprises different sizes, types and makes of the hourglass drum family, belonging to the membranophone instruments. The Yorùbá use the dùndún and bàtá ensembles for social and sacred occasions.

Babalolá (54), in his explanation of ensemble classification in Yorùbá land asserts that traditional artistes have a choice of appropriate types of drums: dùndún or àdàmò, aféré or àgèré, bàtá. He further explains that his study "concentrates on the use of dùndún as an ensemble and the fusion of the kúdí, a member of the bàtá ensemble as a new innovation in contemporary festivals performances." Eúbà (73) describes dùndún as an "instrumental ensemble comprising of hourglass tension drums." Olátúnjí (52) argues that the "dominant instrument determines the name by which the ensemble is called." Babalolá (16), further states that in any burial of a notable personality: "A band of dùndún drummers usually perform at the burial site, recounting, using drum language to recite the attributes of the dead why he was still alive." This takes place briefly before and after the interment. Shortly after, the entire group assemble to put up a social performance of a larger scale to entertain the guests.

\section{The dùndún ensemble}

The number of instruments constituting the dùndún orchestra varies, but only four will be discussed in this study, namely Gúdúgúdú (dual tone, two tone drum), Omele (monotone drum), Keríkerì (monotone, low pitched drum), İyáàlù (multiple tone drum). Omele is distributed into İsáajù and İkeyin meaning the leading and the supporting drum.

The bàtá ensemble is made up of four drums but only kúdí is relevant in this article. These consist of İyáàlù-bàtá (multi-tone drum), Omele-ako (middle tone drum), Omeleabo (low tone drum), Kúdí (triple tone drum).

Yorùbá drums represent the three main tones of Yorùbá language, which are high, medium and low. The iyáàlù is capable of playing all the tones, gúdúgúdú plays two (the middle and the low), isáajù plays one (the middle tone), ikeyin plays one (the low tone) and keríkerì plays one (the low tone). The iyáàlù is the most vocal of all the drums in the ensemble. The earliest experience in which drummers' children are involved with playing drums always involves the gúdúgúdú. Jímòh Aláyandé, in an oral interview, states that "constant playing on this drum helps to make the wrists ever flexible in preparation for the drumming task." In the training process, the child graduates from the gúdúgúdú to play the omele, which he is to play until he is matured in age. He might then play the isáájù and ikeyin for a reasonable number of years before being allowed to play the kerikerì. If the drummer achieves a reasonable standard on the keríkerì he may then proceed to play the ìyáàlù. The drums that make up this ensemble are listed in the appendix following the order for the training of apprentices. 


\section{The bàtá ensemble}

The bàtá ensemble is originally associated with Èsà chant and the Sàngó chant tradition for the worship of Yorùbá divinities. It is now being adopted as a fusion with the dùndún ensemble in social performances given its characteristics of vigour and drive that are capable of stimulating agility and grandiosity. There are four instruments in this ensemble, namely omele méta bàtá, omele-ako, omele-abo and iyáàlù bàtá but only one drum is of importance in the context of the study. This is the three headed drum generally referred to as kudi or omele méta bàtá. The description of construction and playing technique is presented in the appendix.

\section{Social evolution in drumming}

Yorùbá drumming has undergone gradual change in the context of the $21^{\text {st }}$ century. Developments concern the drummers' new perception of the genre, the organisation of the ensemble, the quality of the drums, the audience, and the media devices used in sustaining the genre. Baba Alajede, a chief master drummer in Yorùbá land, asserts that his recent perception of drumming grew out of his exposure to other genres such as Highlife, Juju and Fuji genres. ${ }^{1}$ These genres have regular interactions with other media events that compel the performers to be creative and musically active. Baba's invitation to perform at such events has broadened his thinking and widened his creative competence on the master drum. According to him, "highlife, juju, and fuji are competitive kind of music that features regularly on the television, this makes the artistes to be media conscious and contemporary." He explains further that there are very few occasions for growth beyond the master drummer capacity in the traditional Yorùbá society because most of the responsibility associated with drumming are tied to festivals with regulated drum patterns. The scope of ritual performance justifies or determines the boundary of the drummers. The scope of the other genres permits the drummers to express boundless versatility on their instruments. The interviewee's present skills beat the imagination of his very old father who has never performed outside the scope of the palace and festival settings.

The performance challenges that a drummer faces determine his avenue for growth in Yorùbá land. The organisation of the ensemble today is quite different from what it used to be in the past, as every drum that makes up the ensemble has single representation at performance. Today, multiple representations of instruments are common practices. In the traditional settings, drummers appear in different costumes but today they have uniform costumes for each social event. The position of drummers at performance is also more defined than it used to be. Traditionally, drummers take any position that is convenient for them, but for aesthetic media coverage today they stand side by side based on their hierarchy. Similarly, the dance pattern of the drummers was done at pleasure without any definite or uniform movements while an 
outcome of the technical media coverage is that they now have a more regulated and uniform dance pattern. The media style of recording of events has brought orderliness into the drum ensemble practices in Yorùbá land. Additional recent evidence of modification is the use of drum music performance for advertisement purpose.

\section{Reinventing and diffusing the art of drumming}

Reinventing the art of drumming may mean the revival of the profession in Yorùbá society, the enhancement of the dignity of the practitioners, and the documentation of the drumming tradition in films for future scholarly studies. The revival of the dùndún and the bàtá requires the validation of the role that the two ensembles play in the modern social musical setting of the Yorùbá as the significance of the ensemble spirit in performance is gradually fading away. Other genres of music such as rap, hip-pop, afro beat etc keep attracting the youth and diverting their attention towards Western music. The dùndún and the bàtá ensemble makers try to enhance the aesthetic worth of the drums, for example modern drums now showcases a new and colourful image and the wood for construction is now lighter than in the past. However, their effort is little and not adequately rewarded. Reinventing the ensemble musical culture in Yorùbá land requires salvaging the apprenticeship pattern of instruction that is usually confined in an enclosed setting. This re-awakening requires media documentation on the construction methods of drum making for general use.

Diffusing the art of drumming becomes a necessity in order to promote its tradition beyond the present setting. Intercultural music abounds in the world today and activating the drumming tradition into modern band group will transform its outlook from local to global relevance. Spreading the reach of the ensemble may create a relatively new audience for its performance for broadcasting purposes. The groups could be organized into a more conventional kind of bands that perform at concert halls, schools and government programmes. This will enhance the status of the drummers and also increase their enthusiasm for the profession. The spread of the knowledge of indigenous drumming skills beyond its traditional scope needs to be considered, as well as broadcasting drumming on television and radio stations and integrating them in frequent appearances in films to promote a better rating of the profession. Diffusing the arts of drumming may mean making the ensemble music more appealing to the youth and guaranteeing continuation and vitality of this art.

\section{Conclusion}

Without in any way refusing the writing tradition, that is good and very productive, this article rather appraises the dividend of a more vivid and comprehensive system of documentation that the technical media represents. Moreover, this article shows 
the input of the technical media in the new developments of the drumming art. While the enthusiasm for the indigenous knowledge of the drumming ensemble seems gradually dwindling, the consciousness of the significance of the ensemble spirit in performances of Yorùbá traditional music is the inspiration for this study, with the hope that it may inspire the revitalization of the ensemble music in diversified form for individual, group, and commercial purposes.

\section{Notes}

1. The Juju genre is Yorùbá social music that features full ensembles of drummers and Fuji genre is Yorùbá Islamized social music.

\section{Works Cited}

Alajede, Baba. Interview with Idamoyibo Atinuke Adenike. Lagos, 2005.

Aláyàndé, Jímòh. Interview with Idamoyibo Atinuke Adenike. Lagos, 2005.

Babalolá, S. Adeboye. "İjálá Poetry among the Oyo Yorùbá Communities." Oral Poetry in Nigeria. Eds. Garba Ashiwaju Abalogun and Regina Amadi-Ishiwala. Lagos: Nigeria Magazine, 1981. 3-17.

Eúbà, Akin. "Yorùbá Music in Church: The Development of the New African Art among the Yorùbá of Nigeria." African Musicology: Current Trends 2 (1989): 45-53.

Idamoyibo, Atinuke A. "The Systematic Development of Ijala Genre: The Significance of its Function and Substance in Contemporary Usage." Orafrica 9 (2013): 133-54

Olátúnjí, Ìlátúndé O. Features of Yorùbá Oral Poetry. İbàdàn: Caxton Press, 1984.

Oláníyan, Oluyemi. "Yorùbá Dundun Drumming for the Hunters (llu-Ode): A Discourse of its Text." Journal of Arts and Ideas 1 (2009): 79-92.

-. "Yorùbá Dundun Musical Practice." Nigerian Music Review 10 (2010): 68-79.

Omojola, Bode. "Identity in Nigerian Music." The Performer: Ilorin Journal of the Performing Arts 1.2 (1999): $41-59$.

\section{Appendix}

The dùndún ensemble

The gúdúgúdú

The only non-tension drum in the ensemble is the gúdúgúdú. It is also the only single headed membrane drum in the ensemble. It is the smallest of all the drums and the only one that is not played with drumsticks, but with two twisted leather thongs made from ram or goatskin. It is shaped like a bowl, and the wooden frame is covered by membrane at one end. The membrane is held in position by five small pieces of wood on which the leather straps made of ram skin are fastened.

The gúdúgúdú is the only member among the secondary drums of the ensemble that is dual toned. This is made possible by the black substance pasted on the surface of the membrane. This black substance makes tone variation possible when played. The black substance is called Ida. Whenever the drummer hits the point of the black substance a low tone is produced and whenever he hits the point without the black substance a middle tone is produced. The rope on the drum is hung around the neck region of the player, while the abdomen sustains the drum itself. The rope is made of woven cloth. The leather thongs that are used in playing the drum are either tied to it or detached and kept separately.

\section{Apprenticeship}

Olániyan ("Musical Practice") observed that professionalism in music in Africa requires long period of training according to the traditional method of apprenticeship. Whoever wants to play the gúdúgúdú must start from childhood between the ages of five and eight. Playing at this stage is generally by observation and imitation. It is at this stage that the child is taught how to hang the drum and hold the drum whips. The simplest method of learning to play this drum is by the use of onomatopoeia, 
normally verbalized as follows: "if it finishes, I will go back to the farm (b'ótán ma tún r'oko)." This verbalization technique makes it easy for learners to grasp and internalize the melo-rhythmic structures and themes of the drum.

\section{Omele, isáájù and ikeyìn}

It must be noted here that there is no distinction between the omele, isáajù and ikeyin except that one is made to play the leading role while the other play supporting role. İsáájù and ikeyin drums are shaped like the hourglass drum, but smaller in size. They are both secondary drums of the dùndún ensemble. The drumheads are affixed to each end of the hourglass, and they are connected by several leather thongs running parallel to the wooden shell and laced around the tension hoop of each head. The isáájù is about $13 \mathrm{~cm}$ wide and $33 \mathrm{~cm}$ long, the ikeyin is the same size. They are both tied at the middle, in order to increase the tension, thereby intensifying the rhythmic and dynamic strength. They are only capable of playing one tone each. They are slung on the drummer's shoulder and supported under the armpit. The drummer uses one drumstick each and applies the palms of the left hand at the rim to affect the play of some muting to generate more tones, as they desire.

The isáajù and the ikeyin drums are tuned to slightly different tones, low and middle respectively and are played by two separate drummers, each with a curved stick. The isáájù as the name implies means being at the front; hence it is always leading while the ikeyin follows. These instruments are capable of producing varied rhythmic patterns. African instruments complement one another in performance; hence it is necessary for the secondary instruments to play alternating patterns. In dùndún ensemble for example, if the gúdúgúdú plays a pattern, the isáájù and ikeyìn will play the same rhythm in alternating form. In this pattern, a rhythmic sentence is distributed to two instruments. One plays on the beat while the other has a rest and this alternating process makes each instrument complementary to each other, though they may sound independent of each other. Apart from these, both instruments also help to create a kind of harmony that is peculiar to the dùndún ensemble.

In the process of performance in an ensemble, complex texture is possible from the rhythmic patterns of the drums as they merged in performance.

\section{Kekeríkerì or Aguda}

The keríkerì or aguda is almost as big as the ìnáàlù in size, but unlike the ìyáàlù there are no attachments of secondary bells around it. It is about $16 \mathrm{~cm}$ wide and $35 \mathrm{~cm}$ long. Like the iyáàlù, the kerikerì is made out of a hollow piece of log, covered with membrane at both ends. It is shaped like an hourglass. The drumheads are affixed at both ends of the hourglass. They are connected by several leather strings, which run from one end of the drum to the other. It is therefore, a low-pitched drum. The kerikeri is struck with a curved drumstick, which is about $36 \mathrm{~cm}$ long. The stick is either made from òmò or ota tree. The drum is usually slung on the shoulder and supported by the arm under the armpit. The drumstick is held with the right hand while the drummer manipulates the thongs with his left hand.

\section{The ìyáàlù}

The iyáalù is also known as the talking or mother drum. This is the most vocal or the most eloquent of all the drums of the dùndún ensemble. This instrument is capable of reflecting the tonal nature of Yorùbá speech. It is capable of producing all the quarter tones within the range of an octave. It is the biggest of all the drums in this ensemble and the only one with some secondary bells that are attached around the rim of the body; thereby, producing primary drum sounds and secondary idiophone' sounds.

The ìyáàtù is an hourglass shaped drum, carved by a wood carver. It is a two-headed drum with a leather thong system connecting both membranes to the body of the instrument. The thong is made of goatskin. There are loops at both ends and around the drumheads, made of plaited ropes tightly enclosed in leather. There is a leather ring encircling the two drumheads and holding in place the connecting thong to the loops. A strip of leather or cloth is attached to the drum as handle, in order to make carriage easy. The leather or cloth also has a shoulder pad in order to protect the drummer's shoulder skin. The effectiveness of this shoulder pad is, however, questionable because most drummers complain of some notable marks on their skin, specifically, on their shoulder and waist where the leather strings are hung. In most cases the drummer's skin at the shoulder becomes hardened and dark-spotted. The surface of the iyáalù is about $23 \mathrm{~cm}$ wide, while the length is about $52 \mathrm{~cm}$. 


\section{Construction}

The choice of tree trunk for the carving of ìyáàlù is òmò, rook and timber trees, but the most preferable and qualitative is the òmò tree. In Yorùbá land the wood carvers are responsible for the carving of drums. The drum maker then buys the already carved wood, animal skin, needle, and a piece of cloth to prepare the drum. Customarily, libations are offered to Àyàn (the god of drumming), in order to receive his blessings for drum making. At the end of the libations, the drum maker then soaks the animal skin in water for almost twenty (20) minutes. This makes the leather to be tender, and to reduce the offensive odour.

The second stage of the construction is to have the membrane stretched over the hollowed heads of the drum and to sew it to the rims of the drum. The tension thongs made of ram, goat, sheep, or antelope skin is then passed through the edges of the membrane. The third stage of the construction is the attachment of a leather strap at both ends of the drum to enable the drummer play with ease at performance. The aesthetic use of aso-òkè (Yorùbá traditional attire) is sometimes a replacement for the leather strap. The last stage of the construction is when the membrane is tendered, to achieve the three main tones of the talking drum. This is done by placing the drum in the sun and by beating the membrane without manipulating the thongs, in order to generate the high, medium and low tones.

\section{Playing technique}

The drum is slung on the drummer's shoulder and supported under the armpit. Variation of tones is achieved by beating the membrane with a drumstick. This stick is about 36 to $38 \mathrm{~cm}$ long. Squeezing and releasing of the leather thongs connecting the two drumheads at the middle enables the player to generate the high, middle and low tones of the drum. This is also possible when the player raises and lowers his arm or elbow to depress and release the tension strings. This procedure creates different tension levels on the membrane at both drumheads. Low tone is realized by releasing action on the thongs while high tone is realized by squeezing the thongs. These actions make the production of a variety of tones possible. In the dùndún ensemble, the mother drum (ìyáàlù) acts as the most dominant, while the other instruments play secondary roles. The rhythmic stability of this ensemble is always offset by the iyáalù to avoid a consistent pattern of playing that the secondary instruments are known to represent.

\section{The bàtá ensemble}

\section{Kúdí: omele méta bàtó}

The smallest member of the bàtá ensemble is the omele méta bàtá. It is actually made up of three different drums that are carved separately and tied together firmly as a set. The first of which is àdàmò, which is tuned to the lowest tone; followed by the kúdi, which is tuned to the middle tone. These two drums have a black wax called ida place at the centre of the membrane. Omele ako is the third member of the group. It is tuned to the highest tone and it has no black wax on its membrane. It is hung on the shoulder by the hanging stripes called apá.

The drums are of equal size, measuring about $31 \mathrm{~cm}$ in height, while the membrane that covers each measures about $9.6 \mathrm{~cm}$ and the other smaller end that is not played is about $6.6 \mathrm{~cm}$. Antelope skin or goat skin is used to cover the hollow of the carved wood, (the list of animals' skin in their order of preference). The chosen skin is sewn on each side of the carved wood and leather straps are then used to wrap the wooden body.

\section{Construction}

The most preferable wood used for the construction of kúdí is the òmò tree, though other tree trunks may be used. It is used because of its resistance to rain and sunlight. Jímòh Aláyàndé in a 2010 interview reveals that òmò grows by the wayside and in farmland which make it possible for it to imitate verbal sounds better than the other tree trunks because it is believed that it hears people talk all the time. This claim, however, has not been scientifically proved to ascertain its validity. The drummers do not carve the wood used in building this drum; rather they contract it to wood carvers, who carve according to specifications. The drummer will then buy other materials such as needle, animal skin, wooden pegs, strong ropes and ida (a black substance).that are needed for the completion of its construction,

The first stage of the construction is the smoothing of the shell of the drum, followed by the covering of both ends of the drum with membrane. The next thing is the covering of the wooden frame with animal skin and leather thong system connecting both ends. The second stage of the 
construction is the tying of the three small drums together as one set. This is done by the use of rope or leather. This is followed by the attachment of cloth or leather handle for carriage purposes. This piece of cloth that is used to hang the drum on the shoulder is about 60 to $62 \mathrm{~cm}$ long. The last stage of the construction is the placement of $i d a$, a black substance, on one of the membrane.

\section{Playing technique}

The omele méta is hung across the shoulder with the bigger side of the membrane up and the smaller part of the membrane down. The three drums, as a set, are played with two leather whips. The drums are played on the larger end only. The omele méta plays phrasing referent role in its ensemble. It does this by setting the pace, starting the performance by playing a steady rhythm after which the other drums are introduced one after the other. There are usually two omele méta in bàtá ensemble. One of the kúdí membranes is wet in order to lower its tones, while the other retains its tones as it is kept dry. But in a situation where bàtá is combined with dùndún to form a larger ensemble, only one of omele méta is used. 